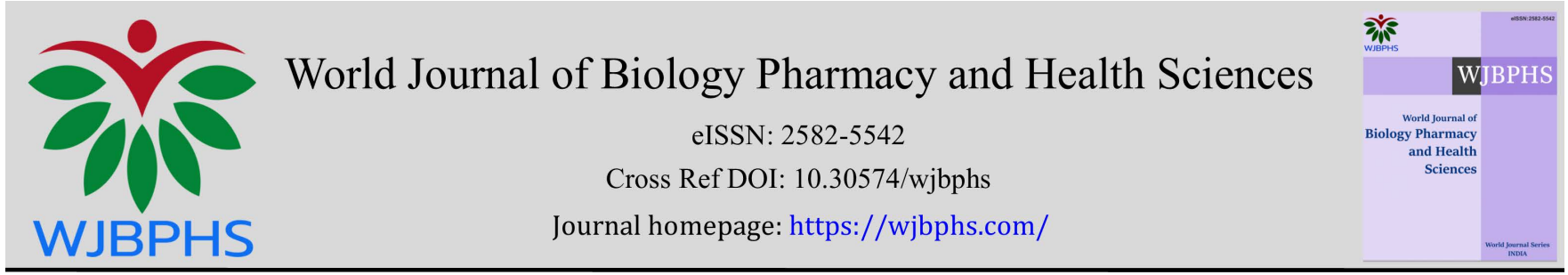

(RESEARCH ARTiCLE)

\title{
Pharmacological studies of Mangifera indica leaf extract
}

\author{
Agrawal RC* \\ Department of Research, Priyamvada Birla Cancer Research Institute, M.P. Birla Hospital J. R. Birla Road, Satna, Madhya \\ Pradesh (INDIA).
}

World Journal of Biology Pharmacy and Health Sciences, 2021, 07(03), 073-079

Publication history: Received on 14 August; revised on 24 September 2021; accepted on 26 September 2021

Article DOI: https://doi.org/10.30574/wjbphs.2021.7.3.0100

\begin{abstract}
The present study was undertaken to explore the phytochemical screening, anti-bacterial and anti-oxidant activities of the hydro-methanolic leaves extract of Mangifera indica using standard screening methods such as disc diffusion and DPPH methods. In phytochemical screening, Mangifera indicaextract showed presence of secondary metabolites such as carbohydrate, phenols, tanins and proteins whereas Saponins were absent. It also showed antibacterial activities against almost all the test organisms. The extracts possessed potent hydroxyl radical scavenging activity against the positive control standard Ascorbic acid. Results denote the presence of hydroxyl radical scavenging principles in the extracts.
\end{abstract}

Keywords: Antibacterial; Antioxidant; Phytochemical; Mangifera indica

\section{Introduction}

Plants and their secondary metabolite constituents have a long history of use in modern western medicine and in certain systems of traditional medicine and are the sources of important drugs such as atropine, codeine, digoxine, morphine, quinine and vincristine etc. Use of herbal medicine in developed countries has expanded sharply in the latter half of twentieth century. The pharmacological treatment of disease began long ago with the use of herb

Mango (Mangifera indica L.) is a juicy stone fruit belongs to the family of Anacardiaceae in the order of Sapindales and is grown in many parts of the world, particularly in tropical countries. The unripe fruits are acidic, acrid, antiscorbutic, refrigerant, digestive and carminative. They are useful in dysentery ophthalmia, eruptions, urethrorrhoea and vaginopathy. The ripe fruits are refrigerant, sweet, emollient, laxative, cardiotonic, haemostatic, aphrodisiac, and tonic. They are also used in vitiated conditions vata and pitta, anorexia, dyspepsia, cardiopathy, haemoptysis, haemorrhages from uterus, lungs and intestine, emaciation, and anemia.

As reported earlier, about 74\% of the known anti-cancer medicines are derived from various plant species [1,2]. Indeed, there are many households dietary products exhibiting anti-cancer potential with minimal side effect that are currently under clinical trials for cancer treatment $[3,4]$. Among these, two important household dietary products that are very common among South Asian communities are Curcumin and Lycopene. Curcumin is a polyphenolic compound isolated from turmeric and this product exhibits anti-microbial, immunomodulatory, and potential cancer chemo preventive efficacy [5,6]. Lycopene is a carotenoid compound abundant in tomatoes and also present in tomato products [7]. As reported earlier lycopene and its derivative exhibit anti-cancer properties. In addition to this the product can also be used in the treatment of cardiovascular diseases [8]. Noratto et al., (2010) compared the anticancer properties of polyphenolic extracts from several mango varieties in cancer cells lines, including Molt-4 leukemia, A- 549 lung, MDAMB-231 breast, LnCap prostate, SW-480 colon cancer cells and non-cancer colon cell line CCD-18Co [9]. Ali et al., (2012)

*Corresponding author: Agrawal RC

Department of Research, Priyamvada Birla Cancer Research Institute, M.P. Birla Hospital J. R. Birla Road, Satna, Madhya Pradesh (INDIA). 
and Timsina et al., (2015) determined that ethanol extract had significant cytotoxicity to HeLa cells and the bioactive fraction from the crude extract had antiproliferative effects with an IC50 value of $<10 \mu \mathrm{g} / \mathrm{ml}[10-11]$. Bhowmik et al., (2009) found that Single oral administration of a dose of $250 \mathrm{mg} / \mathrm{kg}$ body weight produces a potent and strong hypoglycemic effect in Type-2 diabetes on rats. Similar result was found by Reda MY, (2010) [12]. Beltrana AE et al., (2004) reported that anti- inflammatory action of mangiferin is related with the inhibition of NOS and cyclooxygenase2 expression [13]. The possible anti-inflammatory mechanisms of mangiferin include the balance between the overwhelming anti-inflammatory cytokines and proinflammatory mediators, inhibition of inflammatory cellular activations, regulations of inflammatory gene expressions, and enhancements of the cellular resistance against inflammatory injuries [14-16]. ). Chemopreventive properties of mango pulp extract (MPE) was evaluated in alteration in liver of Swiss albino mice. MPE was found to be effective in combating oxidative stress induced cellular injury of mouse liver by modulating cell-growth regulators [17]. The aqueous and ethanol extract of leaves and stems of mango at 50 and $25 \mathrm{mg} / \mathrm{ml}$ has been found sufficient activity against bacteria; Staphylococcus aureus, Streptococcus pyogenes, Streptococcus pneumoniae, Pseudomonas aeruginosa, Candida albicans, Enterococcus faecalis [18]. it is thought that the antibacterial activity of mango extract is due to the presence of gallotannin and mangiferin [19]. The present study carried out on the investigation of phytochemicals screening, anti-oxidant and anti-bacterial activities using in vitro model.

\section{Material and methods}

\subsection{Plant collection and identification}

The leaves of Mangifera indica were procured from Satna (Madhya Pradesh) and authenticated by Botanist, Dr. Manoj tripathi of DRI ,Chitrkoot Madhya Pradesh (India).

\subsection{Chemicals}

All the materials and reagents used for the study were from $\mathrm{CDH}$, Renchem and Hi- Media Ltd., India.

\subsubsection{Preparation of Mangifera indicaleaves extract}

The collected seeds were dried in shade and grinded with mechanical grinder. About $50 \mathrm{~g}$ powder poured in separating funnel with $50 \%$ methanol for $48 \mathrm{hrs}$. The collected residues were kept at $55-60^{\circ} \mathrm{C}$ in water bath to concentrate it and finally transfer into the Hot Air Oven to dry it. About 5.8g crude extract was prepared (Yield=19\%) and used for the further rstudies.

\subsection{Phytochemical screening}

Phytochemicals are nonnutritive plant chemicals that contain protective, disease- preventing compounds. Standard screening test were carried out for various plant constituents. Hydro-methanolic crude extract were screened for presence or absence of secondary metabolites such as alkaloids, tannins, steroids, phenols, flavonoids, saponins and Phlobatannins etc. using standard procedures to identify the constituents as described by Sofowara, Trease and Evans,Harborne.

\subsubsection{Test for Carbohydrates}

A small quantity of extract was dissolved in $4 \mathrm{ml}$ of double distilled water and filtered. The filtrate was subjected to molisch's test to detect the presence of carbohydrates and further addition of Fehling's reagent. It showed the brick red color confirmed the presence of reducing sugar.

\subsubsection{Test for Proteins}

About $2 \mathrm{ml}$ of filtrate was treated with $2 \mathrm{ml}$ of $10 \%$ sodium hydroxide solution in a test tube and heated for 10 minutes. A drop of $7 \%$ copper sulphate solution was added in the above mixture. Formation of purplish violet color indicates presence of proteins.

\subsubsection{Test for Glycosides (Keller-Killani test)}

A portion of the hydro-methanolic plant extract in glacial acetic acid, few drops of ferric chloride and concentrated sulphuric acid are added, and observed for a reddish-brown coloration at the junction of two layers and the bluish green color in the upper layer showed presence of glycosides. 


\subsubsection{Test for Flavonoids}

Three methods were used to determine the presence of flavonoids in the plant sample.

\subsubsection{Test for Free Flavonoids}

A portion of the powdered plant sample was heated with $10 \mathrm{ml}$ of ethyl acetate over a steam bath for $3 \mathrm{~min}$. the mixture was filtered and $4 \mathrm{ml}$ of the filtrate was shaken with $1 \mathrm{ml}$ of dilute ammonium solution. A yellow coloration was observed indicating a positive test for flavonoids.

\subsubsection{Lead acetate test}

$0.5 \mathrm{gm}$ plant extract was heated with double distilled water followed by addition of $1 \mathrm{ml}$ of $10 \%$ lead acetate solution. The yellow precipitate indicates the presence of flavonoids.

\subsubsection{Reaction with Sodium hydroxide}

$0.5 \mathrm{gm}$ plant sample was heated with double distilled water followed by addition of dilute sodium hydroxide. The yellow color indicates presence of flavonoid.

\subsubsection{Test for alkaloids Preliminary test}

$100 \mathrm{mg}$ of plant extract was dissolve in dilute $\mathrm{Hcl}$ afterward the solution was filtered, filtrate was tested with Dragendroff's and Mayer's reagents.

\section{Anti-bacterial activities}

Antibacterial activities of hydro-methanolic extract from leaves of Mangifera indica was investigated using the Disk diffusion method given by Kerby-Bauer Disk Diffusion Susceptibility test.

\subsection{Bacterial strain}

Following gram negative and gram-positive bacterial strain i.e., Escherichia coli, and Bacillus subtilis used for the Antibacterial activities which were received from stock culture of our laboratory.

\subsection{Media}

Nutrient agar broth media were used for the antibacterial activities. Nutrient broth is prepared i.e. $1.3 \mathrm{~g}$ in $100 \mathrm{ml}$ of double distilled water, poured indifferent test-tubes and added bacterial strain in each test-tube. Nutrient Agar media prepared poured in Petri- plates after solidifying swab the bacterial cultures on the plates and allowed for incubation at $37^{\circ} \mathrm{C}$ for $24 \mathrm{hrs}$.

\subsection{Concentration}

4 different concentrations of crude extract were prepared (100\%, 75\%,50\%,25\%). 100\%=1g crude extract in $1 \mathrm{ml}$ of double distilled water freshly prepared afterward serial dilution prepared $75 \%=75 \mathrm{mg}$ in $1 \mathrm{ml}, 50 \%=50 \mathrm{mg}$ in $1 \mathrm{ml}, 25$ $\%=25 \mathrm{mg}$ in $1 \mathrm{ml}$.

\subsection{Study parameter}

Measurement of Zone of Inhibition (In mm).

\subsection{Anti-oxidant activities}

Anti-oxidant activities of Mangifera indica leaves extract (10-100 $\mu \mathrm{g} / \mathrm{ml})$ were determined according to standard DPPH methods.

\section{Results and discussion}

\subsection{Phytochemical screening}

The phytochemical present in the hydro methanolic extract of Mangofera indica leaves extract are carbohydrate, Phenol , Tanins, Protein wheras Saponin were absent (Table 1) 
Table 1 Phytochemical present in the hydromethanolic extract of Mangifera indica leaves extract

\begin{tabular}{|c|c|c|}
\hline S.No. & Phytochemical Test & Hydromethanolic Extract \\
\hline $\mathrm{I}$ & \multicolumn{2}{|c|}{ Test for Carbohydrates and reducing sugars } \\
\hline A & Fehling's Test & + \\
\hline II & \multicolumn{2}{|c|}{ Test for Phenolic compound's } \\
\hline A & Ferric Chloride test & + \\
\hline III & \multicolumn{2}{|l|}{ Test for Tannins } \\
\hline A & Lead Acetatetest & + \\
\hline IV & \multicolumn{2}{|l|}{ Test for Phytosterols } \\
\hline $\mathrm{A}$ & Salkowski Test & _ \\
\hline $\mathrm{V}$ & \multicolumn{2}{|l|}{ Test for Proteins } \\
\hline A & Biuret Test & + \\
\hline VI & \multicolumn{2}{|l|}{ Test for Saponins } \\
\hline A & Foam Test & _ \\
\hline VII & \multicolumn{2}{|l|}{ Test for Flavanoid } \\
\hline A & Lead AcetateTest & - \\
\hline
\end{tabular}

\subsection{Antibacterial Activity}

Table 2 Antibacterial activity of Mangifera indica leaves against bacterial strains

\begin{tabular}{|l|c|c|c|c|}
\hline \multirow{2}{*}{$\begin{array}{l}\text { Name of } \\
\text { microorganisms }\end{array}$} & \multicolumn{4}{c|}{$\%$ Concentration of Extract [zone of inhibition(mm)] } \\
\cline { 2 - 5 } & 25 & 50 & 75 & 100 \\
\hline B. subtilis & 18 & 19 & 20 & 21 \\
\hline E. coli & 20 & 20 & 21 & 23 \\
\hline
\end{tabular}

\subsection{Antioxidant Activity}

The in vitro antioxidant activity of Mangifera indica leaves extract was tested in various concentrations against Ascorbic acid as standard.

Table 3 In vitro antioxidant activity of 50\% methanolic Mangifera indica extracts Vs Ascorbic acid (standard)

\begin{tabular}{|c|c|c|c|c|}
\hline Sr. No. & $\begin{array}{l}\text { Concentration of } \\
\text { ascorbic acid }(\mu \mathrm{g})\end{array}$ & $\begin{array}{l}\% \\
\text { inhibition }\end{array}$ & $\begin{array}{l}\text { TBARS } \\
\text { Mangifera indica } \mu \mathrm{gg})\end{array}$ & $\begin{array}{l}\text { Concentration } \\
\text { inhibition }\end{array}$ \\
\hline 1 & 100 & 31.18 & 100 & 12.97 \\
\hline 2 & 200 & 36.65 & 300 & 14.08 \\
\hline 3 & 300 & 47.89 & 400 & 12.47 \\
\hline 4 & 400 & 57.54 & 500 & 37.72 \\
\hline 5 & 500 & 16.70 & 600 & 42.35 \\
\hline 6 & 600 & 61.87 & 700 & 51.10 \\
\hline 7 & 70 & 71.30 & 800 & 51.10 \\
\hline 8 & 80 & 72.27 & 900 & 10.96 \\
\hline 9 & 90 & & & 13.58 \\
\hline
\end{tabular}


Percentage of TBARS was calculated for both Ascorbic acid and Mangifera indica extract, with the help of formula, for a comparative study. The percentage of TBARS was plotted in the graph in different concentration as per following formula.

$$
\frac{\text { Absorbance of Control }}{\text { Absorbance of control }}
$$

\section{Discussion and Conclusion}

Plants are one of the most important sources of medicines. The role of medicinal plants in promoting the ability of human health to cope with the unpleasant and difficult situations is well documented from ancient times till date all over the world. One of the cardinal goals is the quest to combat the incidence of diseases such as malaria, HIV/AIDS and chronic diseases such as age- related degenerative diseases, cancer and cardiovascular diseases. Medicinal plants are rich in secondary metabolites which are potential sources of drugs and of therapeutic importance. There is increasing interest in the use of plant extracts as therapeutic agents. Mango 'king of fruit' belongs to use pharmacological potential as panacea. it is reported that mango is a potential source of anticancer, anti-diabetic, anti-inflammatory, source of anticancer, anti-diabetic, anti-inflammatory ,antimicrobial drugs as well as it also used as cardio protective, radio protective, recognition of memory and many others. Our result suggest the antibacterial and antioxidant properties if Mangifera indica leaves extract which is important for further study for anticancer and antidiabetic activity of this plant.

\section{Compliance with ethical standards}

\section{Acknowledgments}

The authors are thankful to our dissertation students Ms.Vaishali Singh and Ms. Dahiya for carrying out the above w0ork and Dr. S.K. Maheshwari, Medical Director of M. P. Birla Hospital, Satna for providing lab facilities to carry out above work.

\section{References}

[1] Craig W, Beck L. Phytochemicals: Health Protective Effects. Canadian journal of dietetic practice and research: a publication of Dietitians of Canada = Revue canadienne de la pratique et de la recherche en dietetique: une publication des Dietetistes du Canada. 1999; 60(2): 78-84.

[2] Craig WJ. Phytochemicals: guardians of our health. Journal of the American Dietetic Association. 1997; 97(10): S199-S204.

[3] Garg AK, Buchholz TA, Aggarwal BB. Chemosensitization and radiosensitization of tumors by plant polyphenols. Antioxidants \& redox signaling. 2005; 7(11-12): 1630-47.

[4] Mann J. Natural products in cancer chemotherapy: past, present and future. Nature Reviews Cancer. 2002; 2(2): 143-8.

[5] Aggarwal BB, Sundaram C, Malani N, Ichikawa H. Curcumin: the Indian solid gold. The molecular targets and therapeutic uses of curcumin in health and disease: Springer. 2007; 1-75.

[6] Sa G, Das T, Banerjee S, Chakraborty J. Curcumin: from exotic spice to modern anticancer drug. Al Ameen J Med Sci. 2010; 3: 21-37.

[7] Kong KW, Khoo HE, Prasad KN, Ismail A, Tan CP, Rajab NF. Revealing the power of the natural red pigment lycopene. Molecules. 2010; 15(2): 959-87.

[8] Rao AV, Agarwal S. Role of antioxidant lycopene in cancer and heart disease. Journal of the American College of Nutrition. 2000; 19(5): 563-9.

[9] Noratto GD, Bertoldi MC, Krenek K, Talcott ST, Stringheta PC, Mertens-Talcott SU. Anticarcinogenic effects of polyphenolics from mango (Mangifera indica) varieties. Journal of Agricultural and Food Chemistry. 2010; 58(7): 4104-4112. 
[10] Ali MR, Yong MJ, Gyawali R, Mosaddik A, Ryu YC, Cho SK. Mango (Mangifera indica L.) Peel Extracts Inhibit Proliferation of HeLa Human Cervical Carcinoma Cell via Induction of Apoptosis. Journal of Korean Social Applied Biological Chemistry. 2012; 55:397-405.

[11] Timsina B, Kilingar N. Mango seeds: A potential source for the isolation of bioactive compounds with anti-cancer activity. International Journal of Pharmacy and Pharmaceutical Science. 2015; 7(3):89-95.

[12] Bhowmik A, Khan LA, Akhter M, Rokeya B. Studies on the antidiabetic effects of Mangifera indica stem-barks and leaves on nondiabetic type-1 and type-2 diabetic model rats. Bangladesh Journal of Pharmacology. 2009; 4:110114.

[13] 13 Reda MY, Morsi NR, Tahan EL, El-Hadad MA. Effect of Aqueous Extract Mangifera indica Leaves, as Functional Foods. Journal of Applied Sciences Research. 2010; 6(6):712-721.

[14] 14 Beltrana AE, Alvareza Y, Xaviera FE, Hernanza R, Rodriguezb J, Nunezb AJ et al. Vascular effects of the Mangifera indica L. extract (Vimang). European Journal of Pharmacology 2004; 499:297-305.

[15] Sanchez GM, Re L, Giuliani A, Nuñez AJ, Davison GP, Leon OS. Protective effects of Mangifera indica L .extract, mangiferin and selected antioxidants against TPA- induced biomolecules oxidation and peritoneal macrophage activation in mice. Pharmacology Research 2000; 42:563-565.

[16] 16 Garrido G, González D, Lemus Y, Garcia D, Lodeiro L, Quintero G et al. In vivo and in vitro anti-inflammatory activity of Mangifera indica L. extract. Pharmacology Research 2004; 50:143-149.

[17] Carvalho RR, Pellizzon CH, Justulin L, Felisbino SL, Vilegas W, Bruni F. Effect of mangiferin on the development of periodontal disease: Involvement of lipoxin A4, anti-chemotaxic action in leukocyte rolling. Chemical Biology Interact 2009; 179:344-350.

[18] Nithitanakool S, Pithayanukul P, Bavovada R. Antioxidant and hepatoprotective activities of Thai mango seed kernel extract. Planta Medicine 2009; 75:1118-1123.

[19] Shabani Z, Sayadi A. The Antimicrobial in vitro Effects of Different Concentrations of Some Plant Extracts Including Tamarisk, March, Acetone and Mango. Journal of Applied Pharmaceutical Science. 2014; (5):75-79.

[20] Engels C, Schieber A, Ganzle MG. Inhibitory Spectra and Modes of Antimicrobial Action of Gallotannins from Mango Kernels (Mangifera indica L.). Applied and Environmental Microbiology 2011; 77(7):2215-2223. 